\title{
Interest and Expectation Analysis of International Con- vention Participants to the International Conference
}

\author{
Yasushi Sugiyama *, Tokuro Matsuo *, Kenpei Tei *, \\ Hiroshi Naganuma $^{*}$, Hidekazu Iwamoto ${ }^{\dagger}$
}

\begin{abstract}
Revitalization of local cities is one of the major issues for Japan. The international convention can attract foreign participants to the venue and increase the local economic ripple effect. Therefore, by questionnaires investigation for the interests and expectations of participants, we clarify the needs of participants and present it to local cities / bureaus as reference for planning and developing international conference venues. The results show that respondents are interested in sightseeing local tourist sites, so local government should play an important role in making strategy for repeat visitation of foreign visitors.
\end{abstract}

Keywords: International convention, Questionnaire, Service design, Venue, Tourism

\section{Introduction}

Revitalization of local cities is one of the major issues of our country, and various actions are performed in terms of tourism, economic ripple effect due to inbound which is increasing in recent years is expected. In particular, the international convention is attracting attention as one of inbound business because it can increase the economic ripple effect of the venue. According to the survey made by the Japan Tourism Agency, the economic ripple effect for total Japan by the international conference in FY2015 was announced to be about 590.5 billion yen [1]. Furthermore, the job creation effect for about 54,000 people and the tax revenue effect of about 45.5 billion yen were estimated. In addition, the average consumption per foreign participant of the international conference is estimated to be about 260,000 yen, which is about 1.7 times higher than the average traveling amount of 156,000 yen for all foreigners visiting Japan. Regarding the holding of international conventions, the organizer first plans two to three years before the held time. What is important in planning is to raise the motivation of the participants and make them repeaters of the relevant international conference. Local cities (such as government, bureau,

\footnotetext{
* Advanced Institute for Industrial Technology, Tokyo, Japan

$\dagger$ Josai International University, Kamogawa, Japan
} 
DMO etc.) wanting to invite international conferences propose their own venues and regional features to organizers. It is desirable that this content leads to the interest of the organizer and the satisfaction of participants, which is the key to success of the invitation. In this paper, we conducted a questionnaire survey for interests and expectations concerning international conferences for multinational participants at the academic international convention held in Japan. Based on the survey results, understand the interests and expectations concerning the conference venues and tourism of participants to the international conference to be held in Japan, and clarify the difference depending on nationality. As a result, local cities will be able to design and develop unique venues that consider participants' expectations for attracting international conventions, and can make effective proposals to organizers.

\section{Preliminary Discussion}

\subsection{Inbound Tourism in Convention Business}

Most of international conventions contribute to increase inbound tourists to be attended the international event. In comparison of economic effects between general sightseeing tourism and convention tourism, convention business creates approximately 7-8 times effects from general sightseeing tourism [2][3]. Delegates who participate in the convention stay longer than pleasure travelers [4]. Most of countries emphasize to increase the number of conventions held in their courtiers. In convention business, there a lot of expenses including social functions, publication, facility rental costs, excursion, and several others. Conventions normally have welcome reception, farewell reception, dinner banquet, VIP banquet, and coffee breaks as social functions. These expense helps local economy where the convention is held. For local government, it is important to understand what kind of travel resources are popular by visitors. These are related with local investment on tourism. For example, even though the local city has a big shopping center besides the station, it should not be invested any more if visitors do not come by and purchase anything.

\subsection{Literature}

A lot of related work are presented in literatures. In existing research, convention attendees' perceptions from both small and large event planners in United States are analyzed and discussed by Oppermann. The contribution analyzed the importance of four factors including facilities, cost, image/recreation, and general location. In this contribution, the destination image is discussed [5]. Zhang et al. modified and detailed Oppermann's proposed model [6]. This study did not duscuss only literature review from existing work and also conducted experimentations for convention attendees and questionnaire-based investigations in the contributions. Severt et al. [7] investigated motivations and satisfactions of convention attendees to participate in national events in United States. Wu and Weber [8] also investigated convention participants' perceptions of about motivation of participation by analyzing the importance of select venue facilities, attributes and services. Yoo and Chon [9] investigated, as well as Weber's contribution, convention participation decision-making with five dimensions: (a) destination stimuli, (b) professional and social networking opportunities, (c) educational opportunities, (d) safety and health situation, and (e) travelability. Choi [10] investigated attendees' satisfaction in conventions using eight factors: price, quality of sleeping rooms, hotel personnel, overall affordability of destination, quality of 
meeting rooms, inventory, location, and quality of convenient services. Breiter et al investigated convention facility and its services based on importance-performance-gap [11]. However, these contributions did not discuss improvement of event and conventions using a certain invented method. And also, they did not suggest about a knowledge on business and service model.

\section{Survey}

\subsection{Target}

In order to clarify the expectations and needs concerning "international conference" and "tourism in Japan" of participants on international conferences held in Japan, we conducted a survey of participants of the international conference held in Hamamatsu in Shizuoka in July 2017. For the questionnaire survey, participants handed out a questionnaire survey paper at the time of checkin at the venue and collected them during the conference period.

\subsection{Questionnaire}

The questionnaire consisted from five parts. The first three parts were about the experience of participating in international conventions, and the questions were divided into past, present and future. The questionnaire is about "Participating International Convention" as Part 1, "This International Convention" as Part 2 and "International Convention to be held in Japan in the future" as Part 3. In each part, a) social event, b) meeting facility, c) meeting attendance purpose, d) tourism, e) questions about the host city were considered. Depending on the nature of the question, the answer method may be one choice or multiple choices from different choices. Or, for measurement of degree, one choice was made from 5 stages. (1: Less important/less agree $<2<3$ : Neutral $<4<5$ : Most important / most agree) In Part 4, as a question only for foreign participants, one choose from 5 levels of choice about expectations and interests in Japan visit. Finally, in Part 5 we asked questions about the participant themselves. Table 1 to 5 show the question items and answer options in Part 1 to 5, respectively. The questions in Table 1 are concerned with experience about the attendance of international conference. The questions in Table 2 are concerned with itinerary of the trip from leaving home, until returning to home for each attendee. The questions in Table 3 are concerned with attendees' perception of attending the conference held in Japan. Table 4 also asks about attendees' perceptions about the conference where answerers are attending. Table 5 shows the question items about answerer's personal information.

Table 1: Question items in Part 1

\begin{tabular}{lll}
\hline$\#$ & Question items & Answer items \\
\hline Q1 & How many times have you ever at- & 1.0 time \\
& tended the international conference? & $2.1-10$ times \\
& & $3.11-20$ times \\
& & $4.21-30$ times \\
& & 5.31 times or more \\
Q2 & How many times have you ever at- & 1.0 time \\
& tended the international conference & $2.1-10$ times \\
& held in Japan? & $3.11-20$ times
\end{tabular}




\begin{tabular}{|c|c|c|}
\hline & & 4. $21-30$ times \\
\hline \multirow{6}{*}{ Q3 } & What kind of social event do you ex- & 5. 31 times or more \\
\hline & pect? (Multiple answers allowed) & 2. Welcome Reception Party \\
\hline & & 3. Farewell Reception Party \\
\hline & & 4. Coffee Break \\
\hline & & 5. Excursion \\
\hline & & $\begin{array}{l}\text { 6. Attraction (traditional dance } \\
\text { show etc.) }\end{array}$ \\
\hline \multirow[t]{5}{*}{ Q4 } & Various venues are used as facilities & 1. Modern conference hall \\
\hline & for international conferences, what & 2. Museums, museums \\
\hline & kind of facilities are you interested in? & 3. Historic buildings \\
\hline & (Multiple answers allowed) & $\begin{array}{l}\text { 4. Shrines / Temples / Churches } \\
\text { 5. Hotels }\end{array}$ \\
\hline & & 6. Other ( \\
\hline \multirow[t]{3}{*}{ Q5 } & Are there any venues left in your im- & 1. Yes (City: \\
\hline & pression at the international confer- & 2. No \\
\hline & ences you have attended so far? & 3. do not know \\
\hline \multirow[t]{5}{*}{ Q6 } & To whom person who answered "1. & 1. Modern conference hall \\
\hline & Yes" with the above Q5., What kind & 2. Museums, museums \\
\hline & of facilities are left in your impres- & 3. Historic buildings \\
\hline & sion? & 4. Shrines / Temples / Churches \\
\hline & & 6. Other ( $)$ \\
\hline
\end{tabular}

Table 2: Question items in Part 2

\begin{tabular}{|c|c|c|}
\hline$\#$ & Question items & Answer items \\
\hline$\overline{\mathrm{Q} 7}$ & $\begin{array}{l}\text { What is the purpose of attending this } \\
\text { international conference? (Multiple } \\
\text { answers allowed) }\end{array}$ & $\begin{array}{l}\text { 1. Educational purpose } \\
\text { 2. Opportunities for Networking } \\
\text { 3. Job opportunities } \\
\text { 4. Interesting conference pro- } \\
\text { grams } \\
\text { 5. Career development } \\
\text { 6. Personal development } \\
\text { 7. Association related activities } \\
\text { 8. Visiting friends and relatives } \\
\text { 9. Escape from routine } \\
\text { 10. Conference committee re- } \\
\text { quested you to attend the confer- } \\
\text { ence }\end{array}$ \\
\hline Q8 & $\begin{array}{l}\text { What kind of events do you expect } \\
\text { from this international conference? } \\
\text { (Multiple answers allowed) }\end{array}$ & $\begin{array}{l}\text { 1. Banquet (dinner party) } \\
\text { 2. Welcome Reception Party } \\
\text { 3. Farewell Reception Party } \\
\text { 4. Coffee Break } \\
\text { 5. Excursion } \\
\text { 6. Attraction (traditional dance } \\
\text { show, etc.) }\end{array}$ \\
\hline Q9 & $\begin{array}{l}\text { What is your expectation for a dinner } \\
\text { party? (Choose one) }\end{array}$ & $\begin{array}{l}\text { 1. Least Strong } \\
\text { 2. Less strong } \\
\text { 3. Neutral } \\
\text { 4. More Strong } \\
\text { 5. Most Strong }\end{array}$ \\
\hline Q10 & $\begin{array}{l}\text { Do you have a plan to have sightsee- } \\
\text { ing during this itinerary? (Choose } \\
\text { one) }\end{array}$ & $\begin{array}{l}\text { 1. Yes (Sightseeing plan: } \\
\text { 2. No }\end{array}$ \\
\hline
\end{tabular}


Q11 What are you interested in the tourism resources in Japan? (Multiple answers allowed)

1. Japanese food

2. Shopping

3. City walk

4. Nature

5. Beautiful Scene

6. Japanese Traditional Hotel

7. Hot spring bath

8. History

9. Japan's lifestyle

10. Museum

11. Theme park

12. Night life

13. Japanese traditional art show

14. Manga/Anime

15. Watching Sports (Sumo,

Baseball, Soccer etc.)

16. Golfing

17. Skiing

18. Others

Table 3: Question items in Part 3

\begin{tabular}{lll}
\hline$\#$ & Question items & Answer items \\
\hline \hline Q12 & Allowable travel time from the airport & 1.1 hours \\
/ port of Japan to the venue (Choose & 2.1 to 2 hours \\
one) & 3.2 to 3 hours \\
& & 4.3 to 4 hours \\
& 5.4 hours or more \\
Q13 What kind of venue do you expect for & 1. Modern conference hall \\
the international conference to be held & 2. Art/ museums \\
in Japan? (Multiple answers allowed) & 3. Historic buildings \\
& 4. Shrines / Temples / Churches \\
& 5. Hotels \\
& 6. Other ( \\
Q14 you interested in international & 1. Least Strong \\
conferences held in local cities other & 2. Less strong \\
than Tokyo, Osaka and Nagoya in Ja- & 3. Neutral \\
pan? & 4. More Strong \\
& 5. Most Strong \\
What do you expect for an interna- & 1. Japanese food \\
tional conference in a local city? & 2. Shopping \\
& 3. City walk \\
& 4. Nature \\
& 5. Beautiful Scene \\
& 6. Japanese Traditional Hotel \\
& 7. Hot spring bath \\
& 8. History \\
& 9. Japan's lifestyle \\
& 10. Museum \\
& 11. Theme park \\
& 12. Night life \\
& 13. Japanese traditional art show \\
& 14. Manga/Anime \\
& 15. Watching Sports (Sumo, Base- \\
& ball, Soccer etc.) \\
& 16. Golfing \\
&
\end{tabular}


Table 4: Question items in Part 4

\begin{tabular}{|c|c|}
\hline \# & Question items \\
\hline Q16 & Do you want to visit Japan for your sightseeing travel? \\
\hline Q17 & Do you want to visit Japan to attend an international conference? \\
\hline Q18 & $\begin{array}{l}\text { Convenient transportation availability to Japan is important for you to travel to } \\
\text { the conference venue. }\end{array}$ \\
\hline Q19 & How is the convenience of travel from your country to Japan? \\
\hline Q20 & $\begin{array}{l}\text { What do you want to experience to eat Japanese food during your stay in Ja- } \\
\text { pan? }\end{array}$ \\
\hline Q21 & Do you expect to buy good Japanese traditional souvenir? \\
\hline Q22 & $\begin{array}{l}\text { Do you want to make a time to have sightseeing in Japan after/before the con- } \\
\text { ference? }\end{array}$ \\
\hline Q23 & Do you want to visit local city in Japan after/before the conference? \\
\hline Q24 & How do you think the importance of cost of sightseeing in Japan? \\
\hline Q25 & Do you expect a dinner party in international conference held in Japan? \\
\hline
\end{tabular}

Table 5: Question items in Part 5

\begin{tabular}{|c|c|c|}
\hline \# & Question items & Answer items \\
\hline$\overline{\mathrm{Q} 26}$ & Age & $\begin{array}{llll}1.20 \text { 's } & 2.30 \text { 's } 3.40 \text { 's } & 4.50 \text { 's } & 5 . \\
60 ' s & 6.70 \text { 's and over } & & \end{array}$ \\
\hline Q27 & Gender & 1. Female 2. Male 3. Other \\
\hline Q28 & Nationality & Nationality : $(\quad)$ \\
\hline Q29 & Occupation & $\begin{array}{l}\text { 1. Company Director } \\
\text { 2. Company Manager } \\
\text { 3. Company Employee } \\
\text { 4.Company Temporary employee } \\
\text { 5. Assistant Professor } \\
\text { 6. Lecturer } \\
\text { 7. Associate professor } \\
\text { 8. Full Professor } \\
\text { 9. School Officer } \\
\text { 10. Graduate Student } \\
\text { 11. Undergraduate Student } \\
\text { 12. Others ( }\end{array}$ \\
\hline Q30 & Annual income & $\begin{array}{l}\text { 1. US } \$ 10,000 \text { or less } \\
\text { 2. US } \$ 10,000-30,000 \\
\text { 3. US } \$ 30,000-50,000 \\
\text { 4. US } \$ 50,000-100,000 \\
\text { 5. US } \$ 100,000 \text { or over }\end{array}$ \\
\hline
\end{tabular}

\section{Interest and Expectation for Convention venue}

\subsection{Purpose}

To learn the expectations of participants to the international convention venues is useful when 
local cities study planning and development of their own venue and proposals to organizers. For example, there are cases where local cities with physical restrictions such as access time from the airport compete with the three major metropolitan areas and cities where access is convenient. To clarify the interests and expectations of participants so that they will win the competitors and be an indication to succeed in attracting international conventions. In addition, investigate the expectations for foreign tourists' sightseeing to make it easier for local cities to consider planning, development and proposal of their own tourism resources.

\subsection{Respondent attribute}

Questionnaires were answered by 77 participants from 11 countries. Age of respondents were $26 \%$ in 20 's, $31 \%$ in 30 's, $30 \%$ in 40 's, $6 \%$ in 50 's, $4 \%$ in 60 's and $3 \%$ in no answer as shown in Table 6. Respondents were 79\% male, 18\% female, and 3\% unanswered as shown in Table 7. Table 8 shows answerers' countries and percentages of countries. About $90 \%$ of occupations were university officials (professors, associate professors, assistant professors, lecturers, graduate students, etc.) as shown in Table 9.

Table 6: Age Distribution

\begin{tabular}{cc}
\hline Age & Number of answerers \\
\hline \hline $20 \mathrm{~s}$ & $26 \%$ \\
$30 \mathrm{~s}$ & $31 \%$ \\
$40 \mathrm{~s}$ & $30 \%$ \\
$50 \mathrm{~s}$ & $6 \%$ \\
$60 \mathrm{~s}$ and over & $4 \%$ \\
Unanswered & $3 \%$ \\
\hline
\end{tabular}

Table 7: Sex Distribution

\begin{tabular}{cc}
\hline Sex & Number of answerers \\
\hline \hline Female & $18 \%$ \\
Male & $79 \%$ \\
Unanswered & $3 \%$ \\
\hline
\end{tabular}

Table 8: Country Distribution

\begin{tabular}{cc}
\hline Countries & Number of answerers \\
\hline \hline China & $12 \%$ \\
Croatia & $1 \%$ \\
Danish & $1 \%$ \\
Indonesia & $3 \%$ \\
Japan & $45 \%$ \\
Korea & $3 \%$ \\
Madagascar & $1 \%$ \\
Slovenia & $1 \%$ \\
Taiwan & $21 \%$ \\
Thailand & $7 \%$ \\
USA & $1 \%$ \\
Unanswered & $4 \%$ \\
\hline
\end{tabular}


Table 9: Occupation Distribution

\begin{tabular}{cc}
\hline Occupations & Number of answerers \\
\hline Full professor & $17 \%$ \\
Associate professor & $18 \%$ \\
Assistant professor & $8 \%$ \\
Lecturer & $8 \%$ \\
Graduate Student & $26 \%$ \\
Staff & $4 \%$ \\
Undergraduate student & $1 \%$ \\
Director & $1 \%$ \\
Manager & $3 \%$ \\
Employee & $3 \%$ \\
Part-time employee & $1 \%$ \\
Others & $2 \%$ \\
Unanswered & $8 \%$ \\
\hline
\end{tabular}

\subsection{Expectation of international convention participants to the venue}

In response to "the venue expected at the international conference held in Japan", as shown in Figure 1, the expectation for "modern conference hall" (40/77) is the highest, "historic building" (28/77) "Art / museum" (21/77) are follows it. Also, "Shrines and temples" (7/77) tended to be less expected. On the other hand, as shown in Table 10, for access from the airport to the venue, the allowable travel time from the airport occupied $72 \%$ of the whole with "0-1 hours" and "1-2 hours".From these observations, we could read the preferences of "efficient and reasonable" participants who wish "short travel time" and "modern venue".Furthermore, in the result of the cross analysis of "Expected venue" and "Allowed travel time" (Table 11), 50\% of participants wishing "0-1 hours" wish "modern venue". And 47\% of acceptable participants up to "1-3 hours" were expecting "art / museum" and "historical building". A traveling time from the airport of "1 to 3 hours" means that it is possible to travel over $200 \mathrm{~km}$ if using a highway. Even in local cities with a certain distance from the airport, it was suggested that proposals with "Art/museums" and "historic buildings" as venues could be accepted positively for participants. Figure 2 is a diagram mapping the movable range according to the allowable movement time. Because the whole of Japan is not covered by the permissible travel time of participants, it is desirable to improve the public transportation system and access to the local routes by air route from the hub airport and improve the transit time in order to further utilize the local venues in the future. 


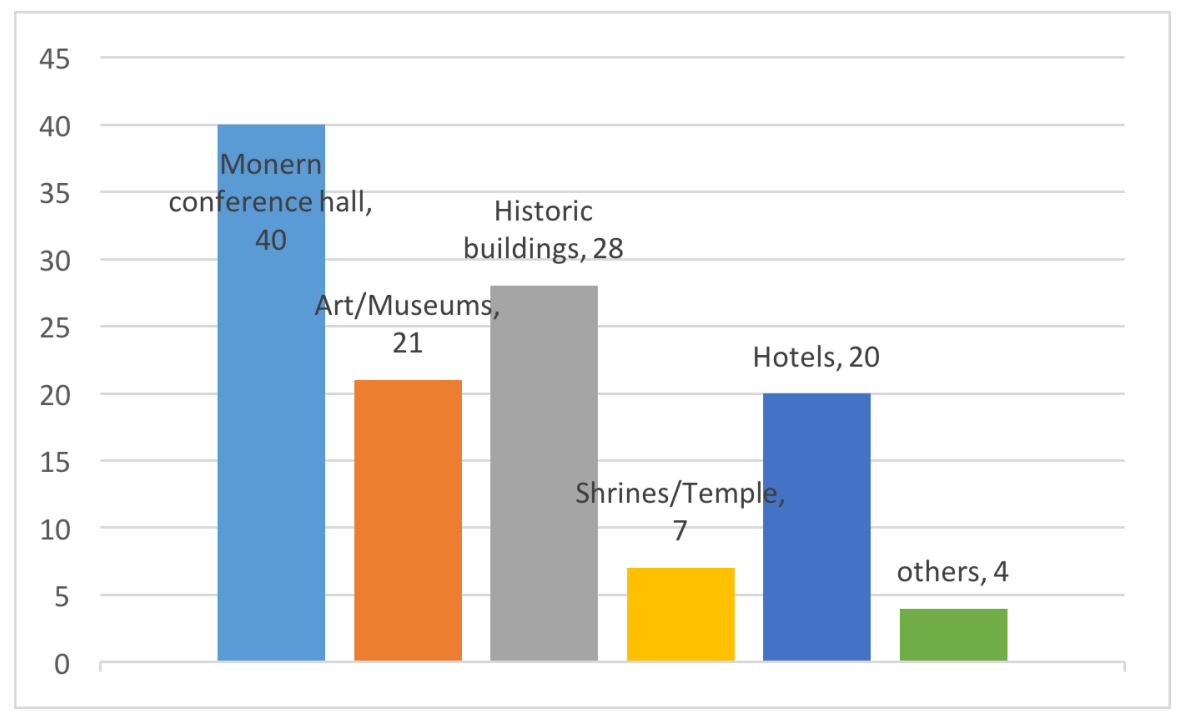

Figure 1: Expected conference venue

Table 10: Allowable travel time from the airport

\begin{tabular}{cc}
\hline Hours & Number of answerers \\
\hline $0-1$ hour & $28 \%$ \\
$1-2$ hours & $43 \%$ \\
$2-3$ hours & $21 \%$ \\
$3-4$ hours & $4 \%$ \\
4 hours or more & $3 \%$ \\
Unanswered & $1 \%$ \\
\hline
\end{tabular}

Table 11: Expected venue and allowable travel time

\begin{tabular}{lll} 
Question items & $0-1$ hour & $1-3$ hours \\
\hline \hline Modern conference hall & $50 \%$ & $27.7 \%$ \\
Art/Museum & $3.6 \%$ & $21.6 \%$ \\
Historical building & $17.8 \%$ & $25.3 \%$ \\
Shrines/Temples & $7.1 \%$ & $4.8 \%$ \\
Hotel & $10.7 \%$ & $19.3 \%$ \\
Others & $10.7 \%$ & $1.2 \%$ \\
\hline
\end{tabular}




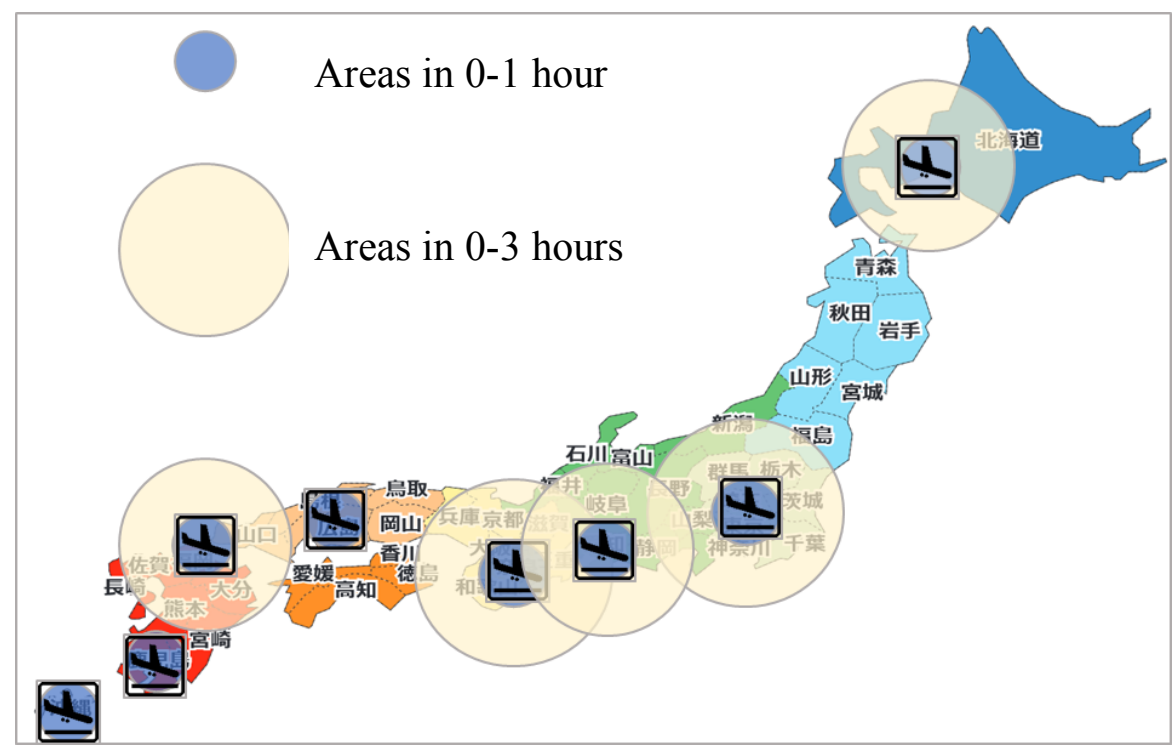

Figure 2: Major airports and allowable travel areas

\subsection{Expectation of foreign participants for sightseeing in Japan}

For the foreign participants, the schedule of sightseeing was "present" was $64 \%$ of the total, and $100 \%$ of participants from "distant Europe, US and Africa" in particular as shown in Table 12. In Table 13, 64\% of the total foreign participants answered the schedule of sightseeing was "yes", in particular, 100\% of participants from "Europe, US and Africa" where is distance from Japan, answered "yes". On the other hand, for participants from "Asia" it was $44 \%$, which is fewer than participants from "Europe, US and Africa". However, when examining "Asia" for each nationality, the tendency varies. 75\% of participants from "Taiwan" and $66.7 \%$ of participants from "China" had plan of sightseeing. Figure 3 shows the concerning the specific interest in Japan tourism resources, "Japanese food", "shopping", "beautiful scene", "nature", "history" etc. are on top, while expectations for "Japanese traditional hotel", "hot spring" were not highly appreciated. It was suggested that tourism services that many Japanese think value is not always highly appreciated by foreigners. As for "shopping", which consumed a large amount of money, "Europe, US, and Africa" tended to have lower willingness to shop than "China" and "Asia" as shown in Table 14. Based on these results, opportunities to increase local consumption could be expanded by proposing sightseeing and particular services during the conference period or before/after the conference. Regarding the content of proposals for tourism and services, planning and proposals based on the needs of foreign visitors to Japan are considered to be effective.

Table 12: Sightseeing plan of foreign participants

\begin{tabular}{cc} 
Answers & Number of answerers \\
\hline Yes & $64 \%$ \\
No & $33 \%$
\end{tabular}


Table 13: Sightseeing plan and participant nationality

\begin{tabular}{llllll}
\hline Answers & Asia & America/Africa & Taiwan & China & Others \\
\hline \hline Yes & $44 \%$ & $100 \%$ & $75 \%$ & $67 \%$ & $67 \%$ \\
No & $56 \%$ & $0 \%$ & $25 \%$ & $33 \%$ & $33 \%$ \\
\hline
\end{tabular}

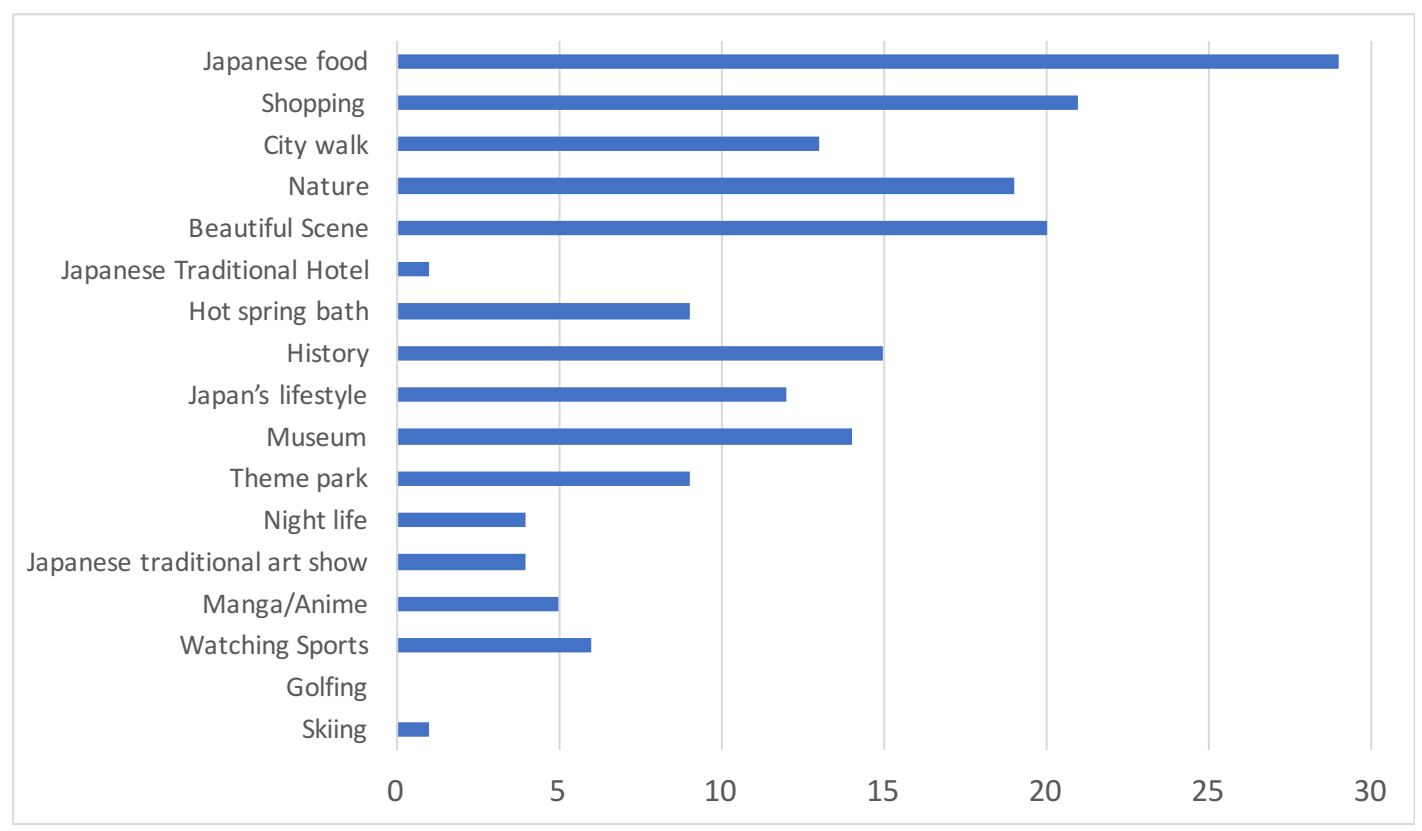

Figure 3: Expected tourism resources in Japan

Table 14: Nationality and expected tourism resources

\begin{tabular}{llllll}
\hline Answers & Asia & America/Africa & Taiwan & China & Others \\
\hline \hline Japanese food & 7 & 5 & 11 & 5 & 1 \\
Shopping & 6 & 2 & 6 & 5 & 2 \\
City walk & 1 & 3 & 7 & 1 & 1 \\
Nature & 4 & 2 & 9 & 3 & 1 \\
Beautiful Scene & 5 & 2 & 11 & 2 & \\
Japanese Traditional Hotel & 1 & & & & \\
Hot spring bath & 3 & 1 & 1 & 4 & \\
History & 1 & 2 & 3 & 5 & 1 \\
Japan's lifestyle & 2 & 3 & 4 & 4 & \\
Museum & 4 & 2 & 4 & 2 & \\
Theme park & 2 & & 1 & & \\
Night life & 2 & 1 & 1 & & \\
Japanese traditional art show & 1 & 2 & 1 & 1 & \\
Manga/Anime & 1 & 2 & 2 & 2
\end{tabular}




\section{Discussion}

In this paper, we surveyed interests and expectations to the conference site through questionnaire answers to convention participants. Half of the participants tend to prefer modern conference halls with good access (within 1 hour from the airport), but even if the access time is longer (one to three hours), "historic buildings" and "Art/Museums ", it was found that about half of the participants liked. Also, it became clear that foreign participants are not very much interested in the "shrines / temples". Regarding Japan tourism, $64 \%$ of foreign visitors to Japan are scheduled to sightseeing, but it became clear that there are variations depending on nationality. Regarding the expected tourism resources, participants from "Asia" are highly interested in "shopping", "Japanese food" and "Beautiful scenes" as a whole. But tendency is difference by nationality, "Taiwan" is "Beautiful scene" "nature" is high, " China "was found to be different as" shopping "and" history ".And it became clear that it is not very interested in 'hot spring' where many Japanese think valuable. In addition to the fact that "shrines and temples" are not expected as venues, it was suggested that the values of Japanese and the interests and expectations of foreign participants do not always agree. In this research, the number of respondents is limited to 77, and it is hard to say that the results of this research are always correctly understanding the interests and expectations of the international convention participants.

\section{Conclusion}

In this paper, we analyzed the convention attendees' expectations in the international convention held in Japan. As shown in the result of survey, a lot of foreigners are interested in visiting local sightseeing places even though their main purposed of visiting is not sightseeing. Most of attendees work in academics and have a good ability to broaden their voice through the Internet, SNS and several other media. Also, some of them may report their colleagues about their visiting to Japan. To enhance the quality of management of sightseeing by local government as well as the quality of convention management by convention organizers, it is one of most important methods to know expectations and satisfactions of convention attendees [12][13]. Through these data acquisition and analysis, local government has a good chance to make a strategy of retention of visitors from foreign countries. In future research, it is necessary to carry out questionnaire on a continuous basis, increase the number of respondents, and accumulate data.

\section{References}

[1] Japan Tourism Agency "Economic Ripple Effect of MICE and Market Research Project Report in 2016", Japan National Tourism Organization, 2016. 
[2] Hidekazu Iwamoto, Tokuro Matsuo, Toshikazu Fukushima, Rieko Fujita, "Analysis of convention bureaus' profile and their perception about destination characteristics", 1st Global Congress of the Special Interest Tourism \& Hospitality (The 1st GloSITH), 2017.

[3] Hidekazu Iwamoto, Tokuro Matsuo, Toshikazu Fukushima, Norihisa Komoda, "On the Convention Bureau's Evaluation of its Regional Characteristics and Convention Facilities", Information Engineering Express, Vol. 2, No. 3, pp. 21-31, 2016.

[4] Samuel Seongseop Kim, Kaye Chon, Kyu Yoop Chung, "Convention industry in South Korea: an economic impact analysis”, Tourism Management, Vol. 24, No. 5, pp. 533-541, 2003.

[5] Martin Oppermann, "Perceptions of Convention Destinations, Journal of Convention \& Exhibition Management", Vol. 1, No. 1, pp. 35-48, 1998.

[6] Hanqin Qiu Zhang, Vivien Leung, Hailin Qu, "A refined model of factors affecting convention participation decision-making”, Tourism Management, Vol. 28, pp. 1123-1127, 2007.

[7] Denver Severt, Youcheng Wang, Po-Ju Chen, Deborah Breiter, "Examining the motivation, perceived performance, and behavioral intentions of convention attendees: evidence from a regional conference", Tourism Management, Vol. 28, pp. 399-408, 2006.

[8] Ann Wu and Karin Weber, "Convention center facilities, attributes and services: the delegates perspective", Asia Pacific Journal of Tourism Research, Vol. 10 No. 4, pp. 399-410, 2005.

[9] Joanne Jung-Eun Yoo and Kaye Chon, "Factors Affecting Convention Participation DecisionMaking: Developing a Measurement Scale", Journal of Travel Research, Vol. 47, pp.113-122, 2008.

[10] J. Choi, "Factors Influencing State Association Planners' Overall Satisfaction with a Convention Experience", Journal of Convention \& Event Tourism, Vol.6, No.4, pp.65-80, 2004.

[11] Deborah Breiter, Ady Milman, “Attendees' needs and service priorities in a large convention center: Application of the importance-performance theory", Tourism Management, Vol. 27, pp.1364-1370, 2006.

[12] Tokuro Matsuo, Toshikazu Fukushima, Hidekazu Iwamoto, "A Challenging of Data Science in Association Research for Convention Management", International Conference on Data Science and Institutional Research (DSIR 2015), 2015.

[13] Tokuro Matsuo, Hidekazu Iwamoto, "Analysis of Motivation of Convention Participants and Proposal of Attendance Management System", IEEE International Conference on Software Engineering, Artificial Intelligence, Networking and Parallel/Distributed Computing (IEEE SNPD 2017), 2017. 